\title{
Optimization Implementation of Foreign Customer Information Submission System (SIPINA)
}

\section{Erwin Harinurdin}

Vocational Education, Finance and Banking Laboratory, Universitas Indonesia

\section{Abstract}

One of the G20 agendas is a commitment to nurturing global cooperation to create global financial stability based on justice principles and mutually agreed rules to achieve just and equal prosperity. Trade relations and investment between countries is an instrument that has been proven able to combat poverty in the last four decades. Asia is an area benefiting from world trade relations that has spurred economic revival and poverty reduction from Japan, South Korea, PRC, ASEAN, India and countries in South Asia.Indonesia as a G2o member country is ready to participate in the implementation of Automatic Exchange of Information (AEOI) cooperation

Corresponding Author: Erwin Harinurdin

Received: 8 June 2018 Accepted: 17 July 2018 Published: 8 August 2018

Publishing services provided by Knowledge $\mathrm{E}$

(c) Erwin Harinurdin. This article is distributed under the terms of the Creative Commons

Attribution License, which permits unrestricted use and redistribution provided that the original author and source are credited.

Selection and Peer-review under the responsibility of the $2 n d$ ICVHE Conference Committee. and the implementation of the principle of Base Erosion and Profit Shifting (BEPS) comprehensively and effectively. Indonesia needs international taxation cooperation to overcome tax evasion. Information exchange cooperation is essential for achieving fair taxation and implementation rules between countries. There is no longer a safe place for tax evaders in the world. The tax liability of the e-commerce corporations must be fair and the greater part should be enjoyed by the country where the transactions are located, not where they are registered. The purpose of this research is to improve the role of foreign customer information delivery system (SIPINA) that is currently only for cooperation with America. Research Method used is qualitative method. Data analysis is done using descriptive analysis. The results of the research indicate that the application of the Foreign Customer Information Delivery System (Sipina) for banking information exchange program or Foreign Account Tax Compliance Act (FATCA) with the US Government becomes the medium for banks to send customer data to the Financial Services Authority that is then sent to the Directorate General of Tax Directorate General of Taxation). The Sipina platform needs to be developed to support the broader context, the Automatic Exchange of Information. Automatic Exchange of Information is expected not only with America, but also with other countries. Completion of the application will serve as a media for reporting customer data both domestically and internationally within the deadline agreed by 101 countries incorporated in the Organization for Economic Cooperation and Development (OECD). Completion of the SIPINA application is expected to further facilitate banking and other financial service providers.

Keywords: tax, e-commerce, financial services 


\section{Introduction}

Baden, a small town in southwestern Germany, became the meeting place of the Finance Ministers and Central Bank Governors of the G20 countries from March 1718,2017 . The meeting was also attended by international institutions such as UN, IMF, World Bank, European Commission, African Development Bank and OECD. The current G20 meeting has a somewhat different atmosphere as it is the first meeting after the election of Donald Trump as President of the United States and the start of the UK exit process from the European Union. The meeting also took place in the middle of elections in France, Germany and the Netherlands - where anti-immigration, refugee and populist sentiments are rising in European countries. (Http://www.kemenkeu.go. id/SP/g20-soon-implementation-exchange-information tax - automatically. April 2, 2017)

The G20 finance ministers and central bankers meeting was preceded by the 'High Level Symposium on Global Economic Governance in a Multipolar World' on March 17,2017 , attended by world's leading Ministers and economic leaders. At the symposium, serious discussions then changed to more openness, when Indonesian Finance Minister Sri Mulyani Indrawati raised his views, questioning the G2o's commitment to maintaining global cooperation to create global financial stability based on justice principles and mutually agreed regulation to achieve Fair shared welfare. Trade relations and investment between countries is an instrument that has been proven able to combat poverty in the last four decades. Asia is an area benefiting from world trade relations that has spurred economic revival and poverty reduction from Japan, South Korea, PRC, ASEAN and India and countries in South Asia. (Ibid. 2017)

The issue of international trade on the development of the global economy including the economy for international trade system agreements must continue to be supported by countries in the world. The commitment to avoid the devaluation of the exchange rate for the sole purpose of the trade competition of each country must be maintained. Nevertheless, the agreement on the importance of continuing to safeguard world trade based on global rules cannot be agreed upon by the Forward Countries. The results are disheartening for signaling that globally binding rules are no longer the basis of world economic and trade relations, meaning powerful states will dictate and dominate relationships according to their own interests - not in the common interest. This should be anticipated by Indonesia in formulating future economic policies. Indonesia should encourage G20 member countries to reinforce its commitment to support a stronger, sustainable, balanced and inclusive growth strategy to 
maintain long-term global growth momentum. Therefore, all policy options including monetary, fiscal and structural reforms should be used jointly and mutually supportive to maximize the effort to drive global growth.

Banking is one of the financial institutions that have an important role in the development of the national economy. The existence of a bank as an intermediary institution in the field of economy brings various impacts in the smooth implementation of development from time to time, both nationally and internationally. Along with the increasing level of community needs, especially in the field of economy encourage the role of banking is increasingly needed in meeting the needs of these communities. The bigger challenge faced by banking institutions is the growth of electronic commerce (e-commerce) as a financial trade between individuals, communities and companies around the world.

Advances in information technology also add to the challenges faced by banks. The development of information technology (IT) led to the rapid development of the type and complexity of bank products and services so that the risks that appears to be larger and varied. In addition, the banking industry that tends to be global also causes the competition between banks to become tighter so that national banks must be able to operate more efficiently by utilizing information technology. On the basis of this, the confronting and related banks need to see the flow of change as a new challenge for them to divert traditional banking gateways to more global and responsive strategies and circumstances.

The Financial Services Authority (OJK) is preparing two new rules for the implementation of an Automatic Exchange of Information (AEOI) program related to financial and tax information. The new rules include the exchange of customer data among partner jurisdictions, including financial services authorities in other countries, as well as the rules of the banking matter. Financial services institutions seek to support the implementation of the Automatic Exchange of Information in accordance with existing legislation corridors. One manifestation of such support is the preparation of rules for financial services institutions in order to be able to convey customer data to be exchanged for information in taxation with partner countries or partner jurisdictions.

There are several laws that need to be finalized to accommodate banking information exchange programs. The law includes General Provisions and Tax Procedures (KUP), Banking Laws, Shari Banking Laws and Capital Market Laws. In addition to the Law as the primary legal umbrella, the government should also prepare a set of supporting or secondary rules to regulate technical matters, either in the form of Regulation of the Minister of Finance and the Regulation of the Financial Services 
Authority. (Http://www.kemenkeu.go.id/SP/OJK-prepare-two-rules-for-exchangedata-customers. April 2, 2017)

In order to increase tax revenue, the potential tax excavation is done by intensification and extensification method. To be able to intensify taxes and tax extensions conducting electronic commerce (e-commerce), of course, required comprehensive knowledge and systems and approaches related to information technology and electronic commerce characteristics.

Along with technological developments as well as ease and cost efficiency in electronic transactions, the potential to increase tax revenue from electronic transaction or e-commerce activities is of course very large although there are still issues that need to be perfected such as transaction security, confidentiality and knowledge adequate. But how the system of business working mechanism needs to be done more in-depth review of the system. Transactions using the internet as a medium for marketing goods and services have weaknesses in terms of supervision by the Directorate General of Taxes; this is because the transaction is done on line where there is no direct interaction between the seller and the buyer. Even the transaction can be done without the need for a fixed place of business. The identity of sellers and buyers is also not known for certain and detailed.

Japan Tax Authority, National Tax Agency (NTA) has developed a system called Kokuzei Sogo Kanri (KSK) or Comprehensive Tax Administration system. As a complement to the KSK system, NTA developed the Wide Area Network (WAN) in an effort toward electronic tax administration system. Furthermore, the Japanese government also established a Professional for E-Commerce Taxation (PROTECT) to conduct inspections, develop examination techniques and investigations about e-commerce business. (Siswanto, Overview of Taxation on E-Commerce. Indonesia Tax Review, Volume IV Issue 42 Year 2005)

Furthermore, the Australian government also established the Australian Taxation Office (ATO) was created for the taxation of e-commerce transactions will not be much different from e-commerce transactions will not be much different from the conventional transactions. This system is a complementary component of the Good and Sales Tax (GST) system that is effectively enforced since 1 July 2000. (Ibid, 2017)

From the aforementioned description, the researcher focuses the problem of research on the readiness of foreign customer information delivery system (SIPINA) as a comprehensive system as a unit or system of government support in dealing with the development of e-commerce trading transactions. This system is expected to become a government information center in terms of information disclosure of 
banking financial services, taxes and other revenue potential of the state obtained from the optimization of the system.

\section{Research Methods}

In order to know the optimization of the implementation of Foreign Customer Information Submission System (SIPINA) in accordance with the points of problem formulation, the purpose, then used the research approach using qualitative research methods. According to Irawan in qualitative research, the methodology used has unique characteristics. These characteristics stem from research issues that start from broad and general questions, flexible, open and qualitative data collection, as well as inferential findings that are inductive and not generalizable. (Irawan, Prasetya, "Logic and Procedure Research, Introduction to Theory and Social Research Practice Guide for Students and Beginner Researchers", Jakarta: STIA LAN Press, 2004 P. 61)

Qualitative methods are also chosen because qualitative methods can provide complex details about phenomena that are difficult to express by quantitative methods. (Anselm Strauss \& Juliet Corbin, Basics of Qualitative Research: Procedures and Techniques Data Theorizing, translations of Muhammad Shodiq \& Imam Muttaqien, Pustaka Pelajar, Yogyakarta, 2003, p. 5) In addition, this method is also chosen because it has the same characteristics with qualitative research features. The qualitative approach is expected to understand the social phenomena studied with a holistic picture by reporting the views in detail and arranged in a scientific background.

This research is intended to understand the existing social phenomena through a deep and holistic picture. In other words this research is done to understand meaningful social actions. This study aims to get a deeper picture and understanding of financial services, banking Indonesia, Customer Information Submission system and the fulfillment of aspects of taxation in Indonesia.

This study aims to provide a description or description of a situation. So the type of research used is a qualitative descriptive method that is done on the Indonesian banking system. In doing this research, data collection from two sources is literature study and documentary study. Qualitative data analysis is an analysis performed on nonnumeric data such as interviews or reading reports from books, articles, and including non-writings such as photographs, drawings or films, in order to find a common pattern in the form of word - Words (ibid, 2004 hal. 99). Referring to the qualitative data analysis proposed by Neuman (W. Lawrence Nauman, Social Research Methods: Qualitative and Quantitatives approach, Fifth Edition, Allyn and Bacon, Boston, 2003, 
hal $448-449)$, the data analysis used in this study is the analysis of qualitative data with the narrative method.

\section{Analysis and Discussion}

The world of banking makes a variety of products created to provide satisfaction to the community which one of them shaped on-line banking and internet banking. Transformation in the trading and financial system after the e-commerce goes very quickly. The traditional view states that the economic and banking system is founded on three elements namely capital, labor and employers. Today it has changed with the technological element as an additional factor, where technology provides a profound change in trade and financial development.

As Herdiana discloses (Herdiana, Ade Dian, Penerapam E-Commerce di Indonesia, Financial Technology Buletin, Oktober 2000), there are generally three perspectives in talking about what is going on in banking. First, rapid development in the field of communication technology has created new tools and benefits in trade. The focus of banking also increases from maintaining the quality of alertness and readiness as well as to maintain the needs and will of the user. Progress given by banking institutions is no longer limited to ATM alone, but also internet banking, online banking and E-cash. Second, globalization and liberalization around the world invite banking institutions to be more creative, competitive, and quick to act to master every opportunity. The goal of globalization is to expand and gain as much marketing as possible, to create an atmosphere of interdependence in certain trade sequences, and to gain the advantages of economic speed. Third, realize the knowledge economy in the world of trade that emphasizes the importance of technology know how to go forward. In knowledge-economic, what is needed is the organization's effort to get as much information and knowledge as possible from other organizations and to be implemented. The merits can be explained that e-commerce helps accelerate and simplify traditional trade flows on new forms of payment and finance aspects. In the banking world, ecommerce reduces transaction costs, moves funds and increases the amount of trade. $\mathrm{E}$-commerce also makes the process of trading and payment faster, more innovative new products also blaze from the use of the trading system.

Bank skills can be measured through three perspectives: operational skills, billing skills, and financial skills. Operational skills can be explained that with the development of the e-commerce model, banks are no longer in the banking circles, but the extent to which the bank can provide satisfaction and convenience desired by consumers 
or customers and provide a response to new problems and requests on branchless banking. E-commerce will also force banks to reduce the number of networks. If more activities can be implemented via the internet then no longer need the bank to provide facilities in dealing with customers. Financial skills look at the bank's efforts to operate at the most optimal cost but deliver the best results. To achieve it needs to fusion system of progress and technology.

The Government shall immediately issue a Government Regulation in Lieu of Law (Perppu) which regulates the exchange of automatic information or automatic exchange of information (AEol) for the benefit of taxation. Government Regulation in lieu of legislation is important as legal umbrella of tax information exchange program. Moreover, the drafting plan has also received 'blessing' from the member states of the Organization for Economic Cooperation and Development (OECD). In principle, the OECD views are the same as those proposed by the government. If the regulation has published on the automatic exchange of information (AEol), then Indonesia will be considered equivalent to other member countries and can exchange banking information automatically.

Currently all governments in the world have committed to implement the policy to strengthen the tax base in their respective countries. The commitment is taken because the countries in the world face the same problem that is difficult to pursue the taxpayers who keep their assets abroad. With the exchange of information automatically, then the taxpayer who hides assets abroad will be easily known.

The Financial Services Authority (OJK) is preparing two new rules for the implementation of an Automatic Exchange of Information (AEOI) program related to taxation. The new rules include the exchange of customer data among partner jurisdictions, including financial services authorities in other countries, as well as the rules of the banking matter. Financial services institutions seek to support the implementation of the Automatic Exchange of Information in accordance with existing legislation corridors. One manifestation of such support is the preparation of rules for financial services institutions in order to be able to convey customer data to be exchanged for information in taxation with partner countries or partner jurisdictions.

The new rules will complement the previously existing provisions. The rule in question is the OJK Regulation number 25 of 2015 related to the exchange of foreign customer data and Minister of Finance Regulation No. 125 of 2015 on Information Exchange Procedures. OJK is also preparing a Circular (SE) for banking. Issuance of the circular letter in order to comply with the common reporting standard (CRS) provisions containing the policy of due diligence for financial services institutions in collecting and 
reporting AEOI supporting information. The circular will contain a banking mechanism for opening foreign customer data for tax purposes.

Preparation of Law Enforcement Rules (Perppu) related to the confidentiality of customer data by the government. It is the rules that will contain articles that supersede several articles related to bank secrecy in the four Laws. The articles are derived from the Law on Banking, Syari Banking, Capital Market, and General Provisions and Tax Procedures (KUP).

The Financial Services Authority (OJK) began refining the application of foreign exchange data exchange for the Automatic Exchange of Information (AEOI) program. OJK currently has the application of the Foreign Customer Information Submission System (Sipina) for banking information exchange program or Foreign Account Tax Compliance Act (FATCA) with the United States Government. Sipina which will become the media for banking send customer data to OJK, which then sent to Directorate General of Taxation (Ditjen Pajak). OJK has also built a reporting system called the system of foreign customer delivery. The Sipina platform is also being developed to support the broader context, the Automatic Exchange of Information. Automatic Exchange of Information is then expected not only with America, but also the 100 countries that are now signing it.

Sipina has been developed since 2015 to facilitate FATCA. However, now the application is still to be refined, because the AEOI's jurisdiction partners reach hundreds of countries. Completion of the application will serve as a media for reporting foreign customer data within the deadline agreed by 101 countries incorporated in the Organization for Economic Cooperation and Development (OECD). Completion of the application will further facilitate banking and other financial service providers, because the current banking world has been concerned with the system Sipina.

Indonesia may be on the blacklist of countries that will not have access to data exchange customers, if not immediately complete the provisions to support the program Automatic Exchange of Information (Automatic Exchange of Information/AEOI). The law and all implementing rules must be issued by June 30, 2017. The government is currently pursuing the completeness of AEOI requirements, including Government Regulation in Lieu of Law, because with such short duration it is not possible to revise the four laws immediately. If the Indonesian government cannot meet the requirements until June 30, 2016, then Indonesia will be categorized into countries that fail to meet the commitment. If fail to meet the commitment, then there will be implications. The Government of Indonesia has declared its commitment to join the AEOI country. Thus, if it fails to meet its requirements, Indonesia will be assessed as a country failing 
to fulfill its own commitments. In addition, Indonesia will also be reported to the $\mathrm{G}_{2} \mathrm{O}$ as a non-cooperative jurisdictions country. There will be heavy sanctions if Indonesia is not incorporated in AEOI. The main thing is that Indonesia has lost access to its citizens' wealth data stored overseas, because no country believes in this country. In addition, Indonesia will also lose the opportunity to obtain declaration of assets abroad by its taxpayers, and considered not as credible as a country.

Indonesia's position desperately needs international taxation cooperation to overcome tax evasion. With the Tax Amnesty can be shown that many Indonesian taxpayers who have not declared assets and income stored overseas. Information exchange cooperation is essential for achieving fair taxation and implementation rules between countries. There is no longer a safe place for tax evaders in the world. The government also reminds the tax liability of companies of the digital economy. The 'digital economy' tax liability should be fair and the bulk of it should be enjoyed by the country where the transaction takes place, not where it is registered. Indonesia as a G2o member country is ready to participate in the implementation of Automatic Exchange of Information (AEOI) cooperation and the implementation of the principle of Base Erosion and Profit Shifting (BEPS) comprehensively and effectively.

Indonesia's experience in implementing the tax amnesty program, where the results show the declared asset is very large, while the repatriated assets are still relatively small. Indonesia views G20 member countries should work together to create a strong and transparent international taxation cooperation program, while still paying attention to the justice and readiness of all countries that want to participate in it. In this case, do not let the country that wants to join the program AEOI and BEPS is then a victim of the program itself due to the inability of the country to prepare them.

Indonesia hopes that with the implementation of the cooperation program, there will be no loophole for international tax avoidance practices and no country uses different tax systems to innovate financial instruments that contradict the spirit of BEPS and AEOI. In addition, Indonesia also states the need for closer taxation cooperation between trading partner countries in order to prevent tax leakage arising from the flow of money through international trade.

Indonesia's desire to become a member of the Financial Action Task Force (FATF) and to request full support from G20 member countries. The presence of Indonesia as a member of FATF will contribute greatly to the world in combating money laundering and terrorism financing (AML/CFT), given Indonesia's position which is included in strategic countries in the world and has an open financial system. The benefits to 
domestic are also enormous where Indonesia can prepare AML/CFT related regulations in line with international standards, and can also actively play a role in building global standards related to AML/CFT.E-commerce is often described as one of three types: business-to-business (B2B), business-to-consumer $(\mathrm{B} 2 \mathrm{C})$ and businessto-government $(\mathrm{B} 2 \mathrm{G})$. About 80 percent of the total value of e-commerce in the world today chooses B2B e-commerce. B2B e-commerce has the greatest profit potential in terms of profit productivity.

The tax implication of business activities with e-commerce arises in the case of tenants of space in the internet service provider (ISP) is a company domiciled abroad. First of all is whether by the presence of an overseas company through a website, the company may be deemed to have a 'permanent establishment' in Indonesia. The definition of 'BUT' as set out in Article 2 paragraph (5) of the Income Tax law indicates that the presence in Indonesia is demonstrated through tangible property in addition to service delivery activities in Indonesia. Thus if an overseas company conducts business activities through the website, in accordance with the definition, this activity does not generate BUT. The same can be said if the foreign company is a company domiciled in a country that has Double Taxation Avoidance Agreement $\left(P_{3} B\right)$ with Indonesia (Surachmat, Rachmanto, Bisnis Indonesia, Edisi 11 \& 18 April 2005.). If the situation is linked to the $\mathrm{P}_{3} \mathrm{~B}$ then two things need to be considered, first in the domestic law of the countries involved having the rule and secondly in accordance with the commentary of the OECD, the existence of the ISP complies with Article 5 of the OECD model.

Japanese government policy has resulted in a realistic revolutionary action toward the development of technology and the global economy in the joints of people's lives. This action is manifested in a knowledge-driven society's knowledge-driven knowledge policy whereby everyone can actively use information technology and fully enjoy its benefits. The Japanese government has worked hard to cultivate an environment based on market power. By using the existing potential Japan State has confidence will be a leader in the development of Information Technology in ways;

1. Build a high speed internet network (ultra-high-speed internet network).

2. Make clear rules for electronic divagnoran (E-commerce)

3. Achieve electronic government based (electronic government) by applying information technology as a means of service to the community.

4. Improving the quality of human resources to face the challenges of technological change and civilization. (Japan: E-Commerce: http://free.vlsm.org/v17/com/ ictwatch/paper./paper031.htm.diaksesJuni2007) The most prominent sectors in 
adopting E-commerce technologies include banking and securities storage (trust banks), information and research services companies, retail trade in goods and trade in motor vehicles and bicycles. Japan Tax Authority, National Tax Agency (NTA), has developed a system called Kokuzei Sogo Kanri (KSK) or Comprehensive Tax Administration System. As a complement to the KSK system and electronic tax reporting and payment system, the National Tax Agency (NTA) develops WAN (Wide Area Network) in an effort to e-administration administration system covering all tax offices in Japan.

Broadly speaking, the tax system to respond to e-commerce transactions applied in Japan is:

a. The information-gathering or transaction-commerce mechanism is conducted through internet search (the internet round search system), magazines, newspapers, websites, information and KSK systems and data base information of the tax office.After finding some information from the internet, Professional for E-Commerce Taxation (PROTECT) will compare the data obtained with SPT data delivered using Kokuzei Sogo Kanri (KSK) system. For example, the taxpayer bank accounts data, which will be verified by confirming it to the relevant bank.

This action can be done because in Japan for the purpose of fulfilling the tax obligation does not apply the terms of bank secrecy. If found differences of tax officers will conduct examination of the taxpayer.

b. Supervision and tax audit of E-Commerce:

Professional Formation for E-Commerce Taxation (PROTECT). Since the formation of PROTECT in February 2000 to December 2000, the team has found unearned income by an Individual Taxpayer, a small, medium and large company of 5,835 million yen. PROTECT team investigation and investigation results have also resulted in consumption tax revenues of 144 million Yen. Professional for ECommerce Taxation (PROTECT) itself has been established 12 Tax Office and consist of 74 staffs who are in several Regional Offices (Regional Tax Bureau) (Siswanto, Overview of Taxation on E-Commerce. Indonesia Tax Review, Volume IV Issue 42 Year 2005. hal 16).

The reasons for establishing the Professional for E-Committees Taxation (PRO$\mathrm{TECT}$ ) at the time were:

- Responding to the rapid growth of e-commerce in Japan, as the growth of the Internet grew. 
- Need to have an appropriate feasibility measurement system (test) associate with e-commerce in the tax administration system.

- Establishment of special team of attaché-commerce audit and other related businesses in the framework of information gathering.

Professional for e-commerce taxation (PROTECT) has a duty, among others, to examine e-commerce transactions. Develop audit techniques for e-commerce transactions. Investigate around new business activities related to e-commerce transactions and get related information about e-commerce.

Furthermore, the tax on consumption known to the State of Australia is the Good and sales tax (GST) which is effectively enforced since July 1, 2000. The rate applied is a single $10 \%$, in contrast to the previous regime of whole sales tax (WST) Goods with varying rates. The issue of GST on e-commerce in Australia consists of two things, namely transactions conducted within Australia (domestic) and international transactions. The Australian Taxation Office (ATO) seeks to ensure that taxation of e-commerce transactions will not be much different from conventional transactions.

Australian companies that deliver or sell to non-residents or exit Australian territory are credited as GST free export of services. A complex problem in determining where the recipient of the surrender is. ATO guidance stipulates that the seller is required to obtain an explanation from the buyer regarding the residence, physical location and use of the sale. The obligation is expected that ATO may determine whether the purchase is GST free or not, so the buyer must inform the address abroad and the goods or services are not used in Australia. ATO also requires sellers to use more reliable methods to determine where buyers live.Efforts to reform taxation in Indonesia are faced with a number of challenging challenges, one of which is the most important concerning low taxpayer compliance. The tax ratio or the ratio between tax revenues and GDP in Indonesia is still 11 percent. In fact, the tax ratio ideally can reach $14-16 \%$. In addition, the number of residents who have a taxpayer ID number (NPWP) of about 32 million. Of these figures, the number of reported tax returns (SPT) is only 12 million. AEOI is a certain periodic, systematic, and continuous transmission of certain information on the taxpayer from a source of income source to a taxpayer resident country. Indonesia has signed the Multilateral Competent Authorities Agreement (MCAA) as the basis for the implementation of AEOI with the state or jurisdiction of partners. Indonesia is included in more than 100 countries committed to start 
exchanging information. The enforcement of AEOI will enable the financial information of clients in financial institutions to be exchanged.Interchangeable data include customer identity, deposit value, interest, and other income. Implementation of AEOI is expected to provide many benefits for Indonesia, among others, the tax authorities can obtain financial information of Indonesian taxpayers who still invest funds in the state or the jurisdiction of partners on a reciprocal basis. In addition, the information exchange mechanism will encourage the financial sector in Indonesia to compete globally and not be viewed in the international financial business sector, considering that AEOI is also applied in other countries. Taxpayers in Indonesia should be grateful for the authority to grant tax forgiveness first before AEOI. Other countries, except India, most directly apply AEOI without any opportunity to declare property through tax forgiveness.

D. Conclusion.

Model and supervision of tax authorities in developed countries such as Japan and Australia have been more advanced in conducting oversight of e-commerce transactions. The existence of a clear definition of e-commerce activities as well as the parties involved in it. Developed models also anticipate tax evasion of ecommerce transactions and provide confirmation of permanent establishment. SIPINA should be developed as a comprehensive system for financial data, banking as well as taxation.

\section{E. Suggestion.}

Given the complexity of e-commerce transactions that have enormous tax potential, it is recommended that the Indonesian government especially the Directorate General of Taxes along with Otorotas Financial Services has a special task unit that handles e-commerce transactions and the delivery of information disclosure of data so as to increase tax revenues.

\section{References}

[1] Anselm Strauss \& Juliet Corbin, Basics of Qualitative Research: Procedures and Techniques Data Theorizing, translations of Muhammad Shodiq \& Imam Muttaqien, Pustaka Pelajar, Yogyakarta, 2003, p. 5

[2] Herdiana, Ade Dian, E-Commerce Agency in Indonesia, Financial Technology Bulletin, October 2000 
[3] Siswanto, Overview of Taxation on E-Commerce. Indonesia Tax Review, Volume IV Issue 42 Year 2005.

[4] Irawan, Prasetya, "Logic and Procedure Research, Introduction to Theory and Social Research Practice Guide for Students and Beginner Researchers", Jakarta: STIA LAN Press, 2004 P. 61.

[5] W. Lawrence Nauman, Social Research Methods: Qualitative and Quantitative approach, Fifth Edition, Ally and Bacon, Boston, 2003, pp. 448-449

[6] Surachmat, Rachmanto, Bisnis Indonesia, Issue 11 \& 18 April 2005

[7] Http://www.kemenkeu.go.id/SP/g20-soon-implementation-exchangeinformation tax - automatically. April 2, 2017

[8] Http://www.kemenkeu.go.id/SP/OJK-prepare-two-rules-for-exchange-datacustomers. April 2, 2017

[9] Japan: E-Commerce: http://free.vlsm.org/v17/com/ictwatch/paper./paperoz1. htm. Accessed June 2007. 